\title{
PENDAMPINGAN PENGENALAN BAHASA INGGRIS YANG MENYENANGKAN (FUN LEARNING) KEPADA ANAK USIA DINI DENGAN MENGGUNAKAN MODEL PEMBELAJARAN LTW (LISTENING, THINKING, WRITING) DIKAMPUNG CUNTING KELURAHAN TANJUNG UNCANG
}

\section{THE ACCOMPANIMENT OF FUN ENGLISH LEARNING TO THE EARLY AGE BY USING LTW (LISTENING, THINKING, WRITING) IN CUNTING KELURAHAN TANJUNG UNCANG}

\author{
Juwita Boneka Sinaga \\ (Pendidikan Bahasa Inggris, Fakultas Keguruan dan Ilmu Pendidikan, Universitas Riau Kepulauan) \\ Juwitaboneka@gmail.com,
}

\begin{abstract}
Abstrak
Pengabdian masyarakat ini bertujuan untuk memberikan wawasan tentang menumbuhkembangkan potensi anak dengan pengenalan bahasa Inggris sejak dini dalam keluarga pada masyarakat melalui Pendampingan Pengenalan Bahasa Inggris yang menyenangkan (Fun Learning) Kepada Anak Usia Dini dengan Menggunakan Model Pembelajaran LTW (Listening, Thinking, Writing). Di Indonesia masih banyakyang belum mengusai bahasa Inggris dikarenakan kurangnya pendampingan pembelajaran yang mereka dapatkan atau baru mendapatkan pembelajaran bahasa asing ketika usia mereka sudah dewasa, sehingga daya tangkap otak kurang optimal.Sasaran pengabdian adalah masyarakat di RW 01 kampung Cunting Kel.Tanjung Uncang Kota Batam.Persiapan dilakukan dengan melakukan survei pendahuluan untuk melihat kondisi di lapangan mengenai masalah yang dihadapi masyarakat. Pelaksanaan dilakukan dengan memberikan layanan informasi menggunakan metodeyang menyenangkan menggunakan model Pembelajaran LTW (Listening, Thinking, Writing).Hasil kegiatanmenunjukkan bahwa: (1). Program pengabdian padamasyarakat dengan kegiatan pendampingan Pendampingan Pengenalan Bahasa Inggris yang menyenangkan (Fun Learning) Kepada Anak Usia Dini dengan Menggunakan Model Pembelajaran LTW (Listening, Thinking, Writing), dapat dilaksanakan dan direspon dengan baik. (2). Pelaksanaan program pengabdian pada masyarakat ini sangat bermanfaat bagi masyarakat sehingga dapat diterapkan para orang tua dengan keterbatasan guna menumbuhkembangkan potensi anak dalam berbahasa Inggris sejak dini.
\end{abstract}

Kata Kunci: model LTW, Pengenalan Bahasa Inggris, Anak Usia Dini

\begin{abstract}
This community service aims to provide the knowledge of growing and developing children's potential by introducing English early in the family to the community through the Fun Learning of English Assistance (Fun Learning) to Early Childhood by Using the LTW Learning Model (Listening, Thinking, Writing). In Indonesia, there are still many people who have not yet mastered English because of the lack of mentoring. They got foreign language learning when they are adults, so the power of the brain is less optimal.The target of community service is community in RW 01 Cunting village, Tanjung Uncang, Batam. Preparations were made by conducting a preliminary survey to see the conditions regarding problems faced by the community. Implementation is carried out by providing information services using a fun method using the LTW learning model (Listening, Thinking, Writing). The results of the activities show that: (1). Community service programs with assistance in the introduction of fun English (Fun Learning) to Early Childhood Using the LTW Learning Model (Listening, Thinking, Writing), can be
\end{abstract}


Minda Baharu, Volume 4, No 1 September 2020

https://www.journal.unrika.ac.id/index.php/MNDBHRU
Doi. $10.33373 /$ jmb.v4i1.2050

P-ISSN 2656-0631; E-ISSN 2614-5944

Hal. 1-10

implemented and responded well. (2). The implementation of community service programs is very beneficial for the community so the parents can develop children's potential in English from an early age.

Keywords: Fun learning, Introduction to English, Early Childhood PENDAHULUAN

Usia dini merupakan masa keemasan (golden age), oleh karena itu pendidikan pada masa ini merupakan pendidikan yang sangat fundamental dan sangat menentukan perkembangan anak selanjutnya.apabila anak mendapatkan stimulus yang baik, maka seluruh aspek perkembangan anak akan berkembang secara optimal. Oleh karena itu, pendidikan anak usia dini harus dapat merangsang seluruh aspek perkembangan anak baik perkembangan perilaku, bahasa, kognitif, seni maupun fisik motorik.

Bahasa merupakan aspek penting dalam perkembangan pada masa bayi dan anak-anak, Menguasai bahasa memungkinkan anak untuk dapat berinteraksi dengan lingkungannya secara efektif. Anak usia 4-5 tahun berada pada tahap pra operasional, yang mana pada tahap ini anak mulai mengembangkan kemampuan berbahasanya. Pemerolehan bahasa pada anak usia dini meliputi 2 tahapan yaitu pemerolehan bahasa pertama dan pemerolehan bahasa kedua (bahasa asing). Bahasa pertama sering disebut juga bahasa ibu, karena anak pertama kali berinteraksi dan belajar dengan ibu (bahasa yang dipakai dalam keluarga). Sedangkan bahasa kedua adalah bahasa anak yang diperoleh setelah bahasa pertama. Bahasa kedua anak di Indonesia pada umumnya bahasa Indonesia dan asing (bahasa Inggris). Pendidikan menurut Syah dalam Handayani, S. (2016)dikatakan bahwa pendidikan berasal dari kata dasar "didik" yang mempunyai arti memelihara dan memberi latihan. Kedua hal tersebut memerlukan adanya ajaran, tuntunan, dan pimpinan tentang kecerdasan pikiran.

\section{METODOLOGI}

1. Bentuk kegiatan

Adapun kegiatan yang dilakukan adalah melakukan program pengenalan bahasa inggris yang menyenangkan (fun learning) kepada anak usia dini dengan menggunakan model pembelajaran LTW (Listening, Thinking,Writing) bagi anak usia dini yang ada di daerah kampung tua cunting RW 01 yang mana diharapkan kegiatan ini mampu meningkatkan hasil prestasi dan minat belajar dari anak anak kampung tua cunting ini dan menumbuhkan kesadaran anak - anak kampung cunting tentang pentingnya belajar bahasa inggris.

2. Teknis pelaksanaan

Undangan pengenalan bahasa inggris disebarkan pada hari rabu, tanggal 07 agustus 2019 melalui ibu pkk dan juga RT kampung tua cunting. Kemudian anak - anak dikelompokkan berdasarkan usia dan kelas. Program ini dimulai dengan memperkenalkan diri dan juga memperkenalkan tim pengajar dan materi bahasa inggris yang akan disampaikan nantinya.

3. Waktu pelaksanaan

Pelaksanaan kegiatan bahasa inggris ini dimulai pada hari minggu,tanggal 18 agustus 2019 dimulai dari pukul 12.00 - 14.00 yang diikuti oleh 21 orang peserta .Pelaksanaan kegiatan pengenalan bahasa inggris ini sekalian bergabung dengan bimbingan belajar karna pada saat itu materi yang diajarkan adalah bahasa inggris. Materi yang disampaikan oleh tim pengajar adalah 
Pemberian Salam (Greetings).Pada materi pemberian salam ini dimulai dari mereka mendengarkan materi dari tim pengajar (listening), kemudian memikirkan arti (thinking) dan penyebutan yang benar kemudiandilanjutkan dengan menulis di buku masing - masing (writing) , dan diakhir pembelajaran dilanjutkan dengan pemberian reward kepada anak - anak yang bisa menjawab dan mengingat pembelajaran yang disampaikan dari tim pengajar .Pada pertemuan selanjutnya tim pengajar mengambil tema part of body, dimulai dari mendengarkan materi dari tim pengajar,dilanjutkan dengan memikirkan letak dan posisi bagian tubuh ,kemudian menuliskan hasil nya di dalam buku yang telah disediakan. 30 menit sebelum kelas belajar bahasa inggris ini berakhir diadakan games dengan menghafal part of body, lalu diadakan games " menyentuh bagian tubuh yang diucapkan tim pengajar ,tetapi jangan mengikuti bagian tubuh yang disentuh tim pengajar." Dan pada saat melakukan games ini para peserta yang gagal melakukan games ini mendapat hukuman, yaitu bernyayi lagu dalam bahasa inggris.

Saat melakukan pengenalan bahasa inggris ini , mendapat respon yang positif dari anak anak kampung tua cunting, dilihat dari peserta yang bertambah di minggu pertama dan kedua dimulai nya program pengenalan bahasa inggris ini.

Tim pengajar juga lebih mudah menyampaikan materi yang diajarkan karna anak anak kampung tua cunting ini sangat antusias untuk mengikuti dan mendengarkan materi pengenalan bahasa inggris ini.Dan program pengenalan bahasa inggris ini pun mendapat apresiasi dari warga kampung cunting. Setiap Proses Pembelajaran di Minggu - minggu berikutnya seperti ini.

\section{PEMBAHASAN}

Dengan melihat definisi tersebut, sebagian orang mengartikan bahwa pendidikan adalah pengajaran karena pendidikan pada umumnya membutuhkan pengajaran dan setiap orang berkewajiban mendidik.Secara sempit mengajar adalah kegiatan secara formal menyampaikan materi pelajaran sehingga peserta didik menguasai materi ajar.

Secara formal pendidikan itu dilaksanakan sejak usia dini sampai perguruan tinggi. Adapun secara hakiki pendidikan dilakukan seumur hidup sejak lahir hingga dewasa. Waktu kecil pun dalam UU 20 Tahun 2003 tentang Sisdiknas pendidikan anak usia dini yang nota bene anak- anak kecil sudah didasari dengan pendidikan yang mengajarkan nilai- nilai moral yang baik agar dapat membentuk kepribadian dan potensi diri sesuai dengan perkembangan anak.

Dalam PP 27 tahun 1990 bab 1 pasal 1 ayat 2, disebutkan bahwa sekolah untuk peserta didik yang masih kecil adalah salah satu bentuk pendidikan pra sekolah yang menyediakan program pendidikan dini bagi anak usia 4 tahun sampai memasuki pendidikan dasarKartono, $\mathrm{G}$. (1976) Di samping itu terdapat 6 fungsi pendidikan yaitu:

- $\quad$ Mengenalkan peraturan dan menanamkan disiplin kepada anak.

- $\quad$ Mengenalkan anak pada dunia sekitarnya.

- $\quad$ Menumbuhkan sikap dan perilaku yang baik.

- $\quad$ Mengembangkan kemampuan berkomunikasi dan bersosialisasi.

- $\quad$ Mengembang ketrampilan, kreativitas, dan kemampuan yang dimiliki anak.

- $\quad$ Menyiapkan anak untuk memasuki pendidikan dasar.

Selain itu tujuan pendidikan juga harus ditanamkan sejak manusia masih dalam 
kandungan, lahir, hingga dewasa yang sesuai dengan perkembangan dirinya. Ketika masih kecil pun pendidikan sudah dituangkan dalam UU 20 Sisdiknas 2003, yaitu disebutkan bahwa pada pendidikan anak usia dini bertujuan untuk mengembangkan kepribadian dan potensi diri sesuai dengan tahap perkembangan peserta didik.

Dengan demikian tujuan pendidikan juga mengalami perubahan menyesuaikan dengan perkembangan manusia. Oleh karena pendidikan dialami sejak manusia lahir hingga dewasa, maka tujuan pendidikan juga merupaka suatu proses. Proses "memanusiakan dirinya sebagai manusia" merupakan makna yang hakiki di dalam pendidikan. Keberhasilan pendidikan merupakan "cita-cita pendidikan hidup di dunia", Akan tetapi tidak selamanya manusia menuai hasil dari proses yang diupayakan tersebut. Oleh karena itu, kadang proses itu berhasil atau kadang pun tidak.

\section{Pentingnya belajar bahasa Inggris}

Bahasa adalah suatu sistem simbol yang digunakan untuk berkomunikasi dengan orang lain. Pada manusia, bahasa ditandai oleh kemampuan individu untuk menciptakan kalimat bermakna yang tidak pernah berhenti dengan menggunakan seperangkat kata dan aturan terbatas, yang menjadikan bahasa sebagai upaya yang sangat kreatif. (Arumsari, Arifin, \& Rusnalasari, 2017)

Di era globalisasi sekarang ini, menguasai bahasa asing menjadi hal yang wajib dimiliki,semakin berkembangnya zaman manusia juga dituntut untuk semakin menguasai IPTEK dan juga berbagai bahasa asing. Saat ini, sudah menjadi hal yang umum masyarakat bisa menggunakan bahasa inggris.Bahasa Inggris merupakan bahasa internasional mempunyai peranan penting dalam kehidupan sehari-hari setiap orang di seluruh dunia.

Bahasa Inggris biasa digunakan dalam pendidikan, pekerjaan, hiburan, komunikasi elektronik, dan perjalanan, dan menjadikan Bahasa Inggris sangat penting untuk dikuasai. Artinya, masyarakat yang berasal dari beragam latar belakang daerah asal, agama dan budaya telah memiliki suatu media yang disepakati untuk berkomunikasi satu sama lainnya, yaitu Bahasa Inggris (Arumsari et al., 2017).

Bahasa Inggris juga telah menjadi bahasa yang mendominasi era informasi untuk menghubungkan dan mentransfer informasi ke seluruh dunia.Hal ini menggiring asumsi bahwa penguasaan bahasa Inggris merupakan kebutuhan yang sangat penting bagi masyarakat modern sekarang ini. Seperti yang dikatakan oleh Fromkin, "English hasbeen called 'the lingua franca of the world" (Bahasa Inggris telah disebut sebagai bahasa pengantar dunia)

Mengajarkan anak berbahasa inggris dapat dimulai sejak dini yaitu disaat anak masih dalam periode emas atau sering disebut dengan istilah Golden Age. Di periode ini anak akan lebih cepat mempelajari bahasa,mengerti apa yang mereka pelajari, meniru apa yang mereka lihat,menghapal apa yang mereka dengar dan mempraktekan nya dikehidupan sehari - hari.

Mempelajari Bahasa Inggris sebagai Bahasa kedua perlu dipelajari sejak usia dini sebelum individu memasuki masa pubertas. Apabila telah mencapai masa pubertas akan banyak kendala yang dihadapi sehingga hasil yang diperoleh tidak maksimal, terutama dalam menguasai pronunciation atau lafal mengucapkan bahasa asing tersebut. (Sinaga, Manurung, \& Marpaung, 2017). 
Beberapa alasan penting nya belajar bahasa inggris :

- $\quad$ Kesempatan mendapatkan pekerjaan lebih besar

- Bahasa inggris adalah bahasa yang menglobal/universal

- Menambah pengetahuan

- $\quad$ Menambah relasi / hubungan

- $\quad$ Meneruskan pendidikan ke jenjang yang lebih tinggi

- $\quad$ Lebih mudah dalam berkomunikasi dengan orang lain.

Tahapan-tahapan Dalam Belajar Bahasa Inggris

Pengajaran bahasa Inggris dilakukan secara bertahap. Sama halnya dengan belajar bahasa Indonesia anak tidak langsung berbicara, membaca dan menulis secara bersamaan. Sebelum bisa berbicara dalam bahasa Indonesia mereka harus mendengarkan terlebih dahulu bahasa Indonesia. Jika mereka tidak pernah mendengarkannya mereka akan mengalami kesulitan dalam berbicara. Itu sebabnya biasanya anak yang tuli juga otomatis bisu karena dia tidak bisa mendengar sehingga tidak bisa menirukannya. Jadi, pada intinya belajar bahasa apapun caranya sama. Berikut ini adalah tahapan-tahapan dalam belajar bahasa Inggris bagi anak:

1. Listening (Mendengar)

Selain mendengar kita berbicara, anak juga bisa mendengar dengan cara dibacakan buku cerita dalam bahasa Inggris, mendengar nyanyian sederhana ataupun menonton DVD atau video berbahasa Inggris. Tapi untuk pengetahuan awal, sebagai pendidik kita harus memilih kata-kata yang sedikit dan sederhana.

2. $\quad$ Speaking (Berbicara)

Setelah anak sering mendengar dalam bahasa Inggris, anak bisa didorong untuk berbicara dalam kalimat-kalimat sederhana.Misalnya, dengan menerapkan waktu 30 menit sehari sebagai waktu keluarga untuk berbicara dalam bahasa Inggris. Layaknya anak usia balitayang baru memulai berbicara, anak juga memulai berbicara dalam bahasa Inggris meskipun dengan satu kata seperti book (buku) ketika melihat kakaknya membawa buku. Lalu kembangkan menjadi kalimat-kalimat pendek seperti, she brings book.

3. Reading (Membaca)

Ada dua metode umum dalam mengajarkan anak belajar membaca dalam bahasa Inggris yaitu whole language approachdan phonic.

a. Whole language approach adalah suatu metode belajar membaca dengan menjadikan bahasa sebagai salah satu kesatuan tidak terpisah-terpisah.belajar membaca juga harus sesuai dengan konteksnya. Metode ini lebih menekankan pada arti suatu kata.Contohnya, ketika melihat kata "cat" (kucing) anak langsung diberitahu bahwa itu bacanya "ket" dan itu artinya kucing.Biasanya anak belajar membaca dengan sistem mengingat (memorize) kata yang sudah pernah disebutkan. Kelebihan metode ini adalah anak lebih cepat bisa membaca tapi akan kesulitan ketika harus menuliskan kata yang dimaksud terutama kata-kata yang cukup panjang.

b. Phonic adalah suatu metode belajar membaca melalui huruf dengan cara mengejanya satu persatu, misalkan "cat" (kucing) berarti dieja "keh-e-teh" dan dibaca "ket". Setiap kata diurai menjadi huruf-huruf.Karena belajar melalui mengeja maka anak memerlukan waktu yang lebih lama untuk bisa membaca.Tapi kelebihannya anak lebih mudah ketika harus menuliskan kata yang dia dengar.Untuk memudahkan anak belajar dan membaca, kita sebagai 
pendidik sebaiknya memilih buku-buku yang sesuai dengan tingkatannya. Misalnya, anak yang baru mulai membaca, sebagai pendidik kita memilih buku-buku yang hanya terdiri dari satu kata misalkan halaman pertama ada gambar buah apel dan di bawahnya ada tulisan This is Apple.Setelah itu bisa dicoba dengan kata yang lain, misalkan I like banana.Anak bisa membuat sendiri buku-buku seperti itu atau mendapatkannya melalui reading A to Z.

\section{Writing (Menulis)}

Ini adalah tahapan yang paling sulit dalam belajar bahasa Inggris, karena ada banyak aturan yang harus dipatuhi. Biasanya orang Indonesia pasti akan kesulitan untuk berbicara dalam bahasa Inggris. Sebenarnya bukan karena tidak bisa melainkan karena takut salah.Padahal meskipun kita salah mengucapkan susunan beberapa kalimat atau salah kata bahasanya lawan bicara kita pasti mengerti. Tapi lain halnya dengan menulis, ketika kita melakukan banyak sekali kesalahan tata bahasa dan cara pengejaan bisa jadi orang yang membaca tulisan kita tidak mengerti apa yang kita tulis. Karena ini relatif sulit, maka menulis menjadi tahapan terakhir.Sebagai pendidik kita tidak boleh terburu-buru mengajarkan grammar atau menulis apabila anak belum menguasai tiga tahap sebelumnya.

Bila guru mengajarkan mata pelajaran kepada peserta didiknya, ia tidak hanya mengutamakan materi yang disampaikan akan tetapi juga memperhatikan anak itu sendiri sebagai manusia yang harus dikembangkan kepribadiannya, Lauder.A. (2008).

Pada saat melaksanakan program pengenalan bahasa inggris ini,terlihat anak anak sangat antusias dalam menerima pelajaran ini, dan peserta yang hadir juga cukup banyak mengikutinya. Materi yang diajarkan juga mudah dipahami oleh peserta didik karna materi yang diajarkan adalah materi yang cukup menarik untuk dibahas.

Tim pengajar juga menyampaikan materi dengan sangat sistematis dan diselingi dengan beberapa games dan lagu yang membuat para peserta antusias ingin belajar bahasa inggris.Dalam mengatasi rasa bosan terkadang tim pengajar melakukan beberapa games yang menarik bagi para peserta les gratis ini,dan juga pemberian reward kepada peserta yang mampu menjawab pertanyaan yang diberikan oleh tim pengajar.

Program pengenalan bahasa inggris ini sangat sukses menarik perhatian para anak anak untuk belajar bahasa inggris, program ini juga mampu menjelaskan betapa pentingnya belajar bahasa inggris diusia dini yang akan menjadi bekal untuk peserta didik di kehidupan kedepannya,karna semakin berkembangnya zaman dibutuhkan juga orang orang yang cekatan dan mampu bertahan di perkembangan ilmu pengetahuan dan teknologi saat ini.

\section{KESIMPULAN DAN SARAN}

\section{KESIMPULAN}

Pendidikan adalah proses pengubahan sikap dan perilaku seseorang atau sekelompok orang dalam usaha mendewasakan manusia melalui upaya pengajaran dan pelatihan. Sebagian orang mengartikan bahwa pendidikan adalah pengajaran karena pendidikan pada umumnya membutuhkan pengajaran dan setiap orang berkewajiban mendidik. 
Secara formal pendidikan itu dilaksanakan sejak usia dini sampai perguruan tinggi. Adapun secara hakiki pendidikan dilakukan seumur hidup sejak lahir hingga dewasa. Oleh karena pendidikan dialami sejak manusia lahir hingga dewasa, maka tujuan pendidikan juga merupaka suatu proses. Proses "memanusiakan dirinya sebagai manusia" merupakan makna yang hakiki di dalam pendidikan.

Di era globalisasi sekarang ini, menguasai bahasa Inggris menjadi hal yang wajib dimiliki,semakin berkembangnya zaman manusia juga dituntut untuk semakin menguasai IPTEK dan juga bahasa asing.

Mengajarkan anak berbahasa inggris dapat dimulai sejak dini yaitu disaat anak masih dalam periode emas atau sering disebut dengan istilah golden age. Di periode ini anak akan lebih cepat mempelajari bahasa,mengerti apa yang mereka pelajari,meniru apa yang mereka lihat,menghapal apa yang mereka dengar dan mempraktekan nya dikehidupan sehari hari.Pada saat melaksanakan program pengenalan bahasa inggris ini,terlihat anak anak sangat antusias dalam menerima pelajaran ini, dan peserta yang hadir juga cukup banyak mengikutinya. Materi yang diajarkan juga mudah dipahami oleh peserta didik karna materi yang diajarkan adalah materi yang cukup menarik untuk dibahas.

\section{SARAN}

Penulis menyadari bahwa anak - anak di Kampung Tua Cunting ini memiliki potensi yang cukup tinggi dalam belajar bahasa inggris, hanya saja kurang nya dorongan dari orang tua dan lingkungan sekitar.Oleh karena itu dibutuhkan edukasi bagi para orang tua tentang pentingnya belajar bahasa inggris diusia dini, terutama di zaman yang semakin modern ini.

Penulis juga menyadari bahwa laporan ini masih banyak kekurangan dan jauh dari kata sempurna.Oleh karena itu, penulis mengharapkan kritik dan saran yang membangun dari para pembaca sekalian. 
Hal. 1-10

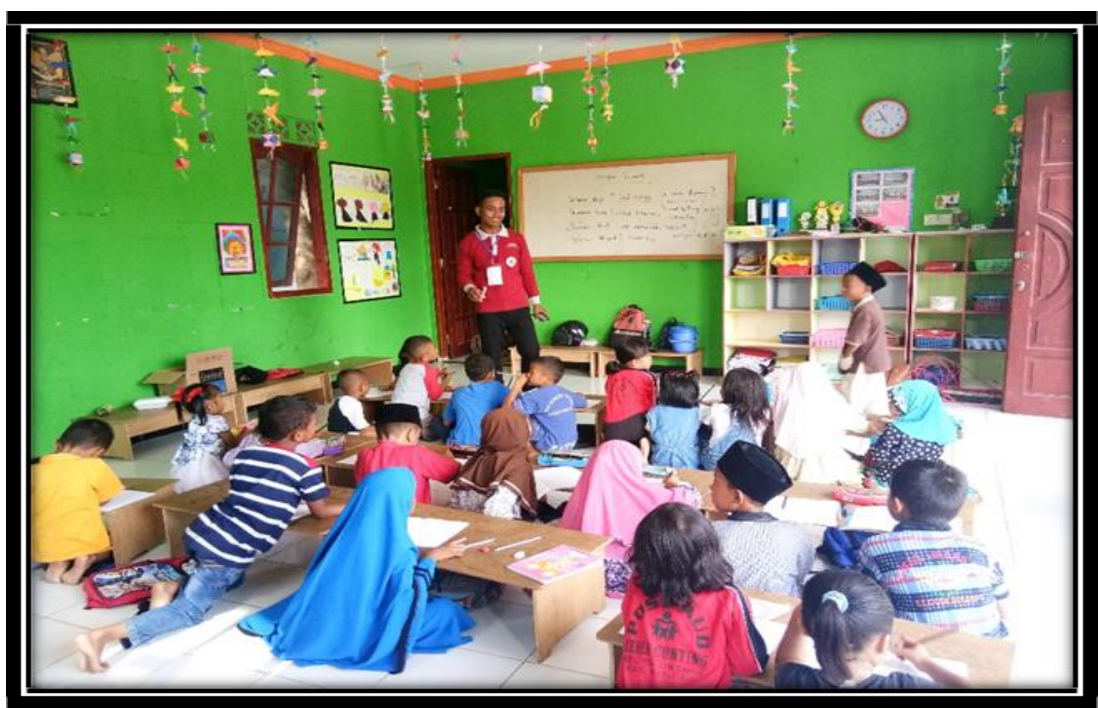

Figure 1. Mengajak anak - anak untuk berani tampil di depan untuk mengingat dan menyampaikan materi yang diberikan

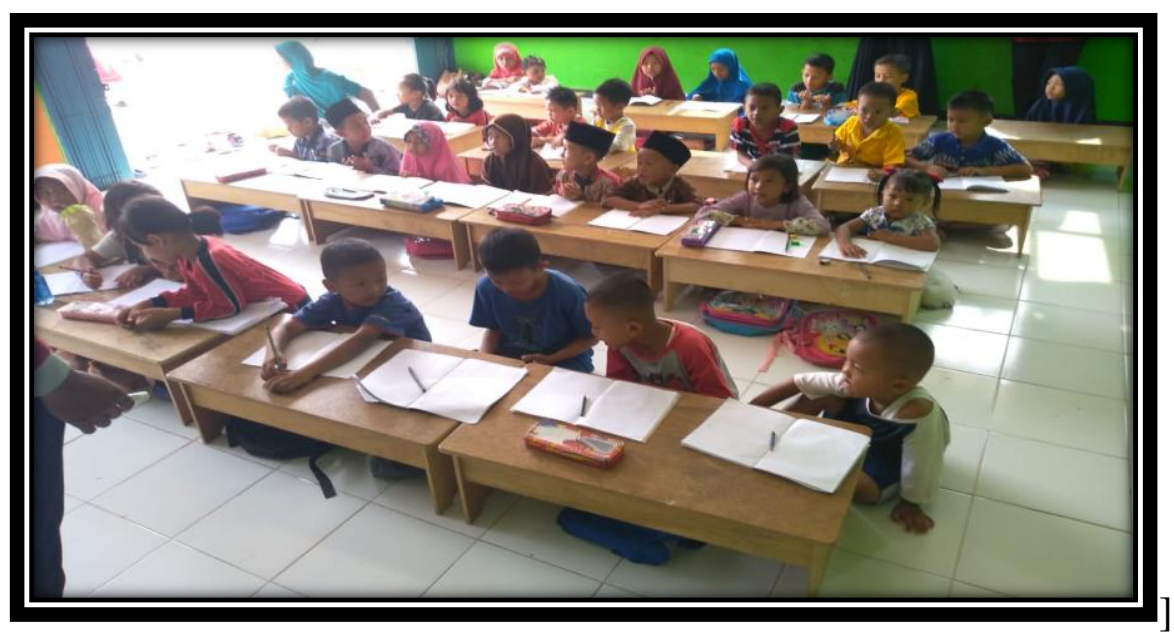

Figure 2. Suasana Belajar Mengajar 


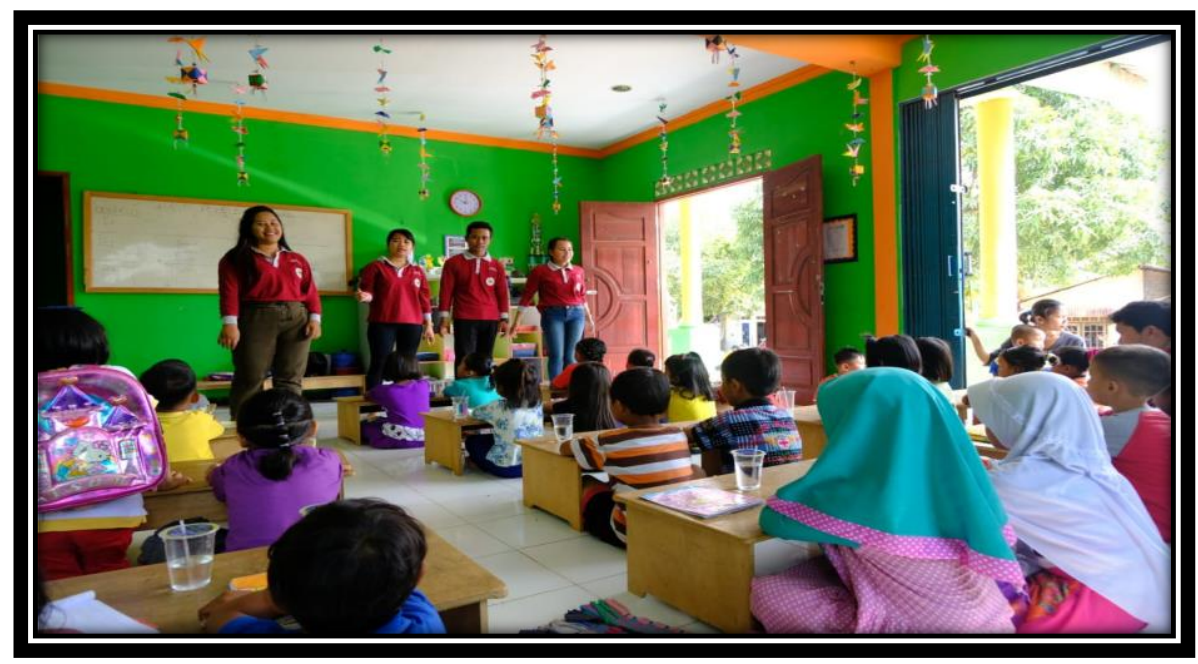

Figure 3. Introduction

\section{REFERENSI}

Arumsari, A. D., Arifin, B., \& Rusnalasari, Z. D. (2017). Pembelajaran Bahasa Inggris pada Anak Usia Dini di Kec Sukolilo Surabaya. Jurnal PG-PAUD Trunojoyo: Jurnal Pendidikan Dan Pembelajaran Anak Usia Dini, 4(2),133. https://doi.org/10.21107/jpgpaud.v4i2.3575

Dardjowidjojo, S. (2003a). The Role of English in Indonesia: A Dillema. In K. E. Sukamto (Ed.), Rampai Bahasa, Pendidikan, dan Budaya: Kumpulan Esai Soenjono Dardjowidjojo (pp. 63-82).

Handayani, S. (2016). Pentingnya Kemampuan Berbahasa Inggris Dalam Menyongsong ASEAN Community 2015. Jurnal Profesi Pendidik, 3(1), 102-106.

Kartono, G. (1976). kedudukan dan Fungsi Bahasa Asing di Indonesia (The Status and Function of Foreign Languages in Indonesia). In A. Halim (Ed.), Politik Bahasa Nasional (National Language Politics) (Vol. 2, pp. 117-126).

Lauder, A. (2008). The Status and Function of English in Indonesia: A Review of Key Factors. Makara. Social Humaniora, 12(1), 9-20.

Muid, A. (2015). Pentingnya Bahasa Inggris dan Bahasa Arab pada Kurikulum Pendidikan. Jurnal Ilmu Pendidikan Islam, 14(2), 32-43.

O’grady, W. (2005). How Children Learn Language. Cambridge: Cambridge University Press.

Rohmah, S. N. (2009). Eksistensi Bahasa Indonesia dan Bahasa Inggris Dalam Ilmu Pengetahuan 
di Era Globalisasi. Pendidikan Bahasa Dan Sastra, 1-10.

Sinaga, J. B., Manurung, S., \& Marpaung, J. E. (2017). Bimbingan Belajar Bahasa Inggris Untuk Anak Usia Dini Di Kelurahan Buliang Rw 18. Minda Baharu, 1(1), 33-41. https://doi.org/10.33373/jmb.v1i1.1171

Syamsu Yusuf L.N..(2001). Psikologi Perkembangan Anak dan Remaja. Bandung:Remaja Rosdakarya.

Tyaningsih, A. R. (2016). Pembelajaran Bahasa Inggris Pada Anak Usia Dini Berbasis Proses Pemerolehan Bahasa Pertama. Pendidikan Bahasa Dan Sastra, 3, 74-82.

Valipour, V., \& Davatgari, H. (2014). Differences between Children and Adults in Foreign Languange Pronunciation and Gramatical Rules Learning. Indian Journal of Fundamental and Applied Life Sciences Vol. 4 (3), pp. 195-198. 